\title{
STATUS OF CARBOHYDRATE METABOLISM IN DAIRY COWS WITH KETOSIS
}

\author{
M. Simonov ${ }^{1}$, V. Stybel ${ }^{1}$, I. Petrukh ${ }^{2}$,V.Vlizlol, \\ m.simonov@ukr.net
}

${ }^{1}$ National University of Veterinary Medicine

and Biotechnologies named after S. Gzhytsky,

50 Pekarska str., Lviv 79010, Ukraine

${ }^{2}$ Institute of Animal Biology NAAS,

38 V. Stusa str., Lviv 79034, Ukraine

This paper contains analysis of carbohydrate metabolism and hormonal regulation of energy metabolism in ketotic cows. It has been revealed that glucose concentration in blood was lower by $29.3 \%(P<0.01)$ in comparison with healthy animals, which is a result of imbalance between energy income with food and energy expenditure for metabolic processes and milk synthesis. Under energy deficit conditions in organism of diseased cows insulin level decreased by $54.7 \%$, $(P<0.01)$ and cortisol level increased by $41 \%(P<0.01)$. This shows evidence of gluconeogenesis intensification by means of lipolysis and proteolysis. At the same time, plasma level of ketogenic amino acids was higher and level of glycogenic amino acids was lower: the concentration of phenylalanine, tyrosine and leucine increased by $22.2 \%(P<0.05), 3.8 \%$ and $62.5 \%(P<0.01)$, respectively, and the level of alanine, arginine and asparagine decreased by $19 \%, 32.8 \%$ and $30.2 \%(P<0.05)$, respectively, in comparison with healthy animals. The obtained results suggest alteration of ketone bodies usage by muscle tissue in the function of energy material. The animals with disease experience intensified lipid oxidation and usage of ketogenic amino acids, which results in compensation of energy deficit, but leads to accumulation of ketone bodies in blood.

Keywords: COWS, KETOSIS, GLUCONEOGENESIS, CARBOHYDRATE METABOLISM, AMINO ACIDS, INSULIN, CORTISOL

\section{СТАН ВУГЛЕВОДНОГО ОБМІНУ У МОЛОЧНИХ КОРІВ, ХВОРИХ НА КЕТОЗ}

\author{
М. Сімонов ${ }^{1}$ В. Стибель ${ }^{1}$, I. Петрух², В. Влізло ${ }^{1,2}$ \\ m.simonov@ukr.net
}

${ }^{1}$ Львівський національний університет ветеринарної медицини

та біотехнологій імені С. З. Гжицького,

вул. Пекарська, 50, м. Львів, 79010, Україна

${ }^{2}$ Інститут біології тварин НААН,

вул. В. Стуса, 38, м. Львів, 79034, Україна

У роботі проведено аналіз вуглеводного обміну та досліджено гормональну регулячію енергетичного обміну в корів, хворих на кетоз. Встановлено, щзо концентрація глюкози у крові корів, хворих на кетоз, була на 29,3\% $(P<0,01)$ нижчою, ніж у здорових тварин, щзо є результатом невідповідності надходження енергї з кормом і ї витратами на метаболічні процеси та синтез молока. За дефіциту енергії в організмі хворих корів відбулося зниження рівня інсуліну на 54,7\%, (P<0,01) та зростання кортизолу на 41\% $(P<0,01)$. Це свідчить про посилення глюконеогенезу у період енергетичного дефіциту за рахунок ліполізу та протеолізу. Водночас у плазмі крові хворих корів було зареєстровано вищиии вміст кетогенних амінокислот та нижчий - глікогенних: вміст фенілаланіну, тирозину та лейцину зростав на 22,2 \% $(P<0,05), 3,8 \%$ і 62,5\% $(P<0,01)$ відповідно, а аланіну, аргініну та аспарагіну - знижувався, відповідно, на 19\%, 32,8\% та 30,2\%, (P<0,05) порівняно зі здоровими тваринами. Отримані дані свідчать про порушення використання кетонових тіл м'язовою тканиною як енергетичного матеріалу і окиснення вуглеводів. У хворих тварин підвищилось окиснення ліпідів та використання кетогенних амінокислот, ш⿻о вирівнює енергетичну недостатність, але супроводжується накопиченням у крові кетонових тіл.

КЛючові слова: КОРОВИ, КЕТОЗ, ГЛЮКОНЕОГЕНЕЗ, МЕТАБОЛІЗМ ВУГЛЕВОДІВ, АМІНОКИСЛОТИ, ІНСУЛІН, КОРТИЗОЛ 


\title{
СОСТОЯНИЕ УГЛЕВОДНОГО ОБМЕНА В МОЛОЧНЫХ КОРОВ, БОЛЬНЫХ КЕТОЗОМ
}

\author{
М. Симонов ${ }^{1}$, В. Стыбель ${ }^{1}$, И. Петрух², В.Влизло ${ }^{1,2}$ \\ m.simonov@ukr.net
}

\author{
${ }^{1}$ Львовский национальный университет ветеринарной медицины \\ и биотехнологий им. С. 3. Гжицького, \\ ул. Пекарская, 50, г. Львов, 79010, Украина \\ ${ }^{2}$ Институт биологии животных НААН, \\ ул. В. Стуса, 38, г. Львов, 79034, Украина
}

\begin{abstract}
В работе проведен анализ углеводного обмена и исследовано гормональную регуляцию энергетического обмена у коров, больных кетозом. Установлено, что кониентрация глюкозы в крови коров, больных кетозом, была на 29,3\% (P<0,01) ниже, чем у здоровых животных, что является результатом несоответствия поступления энергии с кормом и ее затратами на метаболические прочессы и синтез молока. При дефиците энергии в организме больных коров произошло снижение на 54,7\% $(P<0,01)$ уровня инсулина и рост на $41 \%(P<0,01)$ кортизола. Это свидетельствует об усилении глюконеогенеза в период энергетического дефицита за счет липолиза и протеолиза. В то же время в плазме крови больных коров было зарегистрировано более высокое содержание кетогенных аминокислот и более низкое - гликогенных: содержание фенилаланина, тирозина и лейцина возросло на $22.2 \%(P<0.05), 3.8 \%$ и $62.5 \%(P<0.01)$ соответственно, а аланина, аргинина и аспарагина - снизилось, соответственно, на 19\%, 32.8\% и $30.2 \%(P<0.05)$ по сравнению со здоровыми животными. Полученные данные свидетельствуют о нарушении использования кетоновых тел мышечной тканью в качестве энергетического материала и окисления углеводов. У больных животных повысились окисление липидов и использование кетогенных аминокислот, что выравнивает энергетическую недостаточность, но сопровождается накоплением в крови кетоновых тел.
\end{abstract}

КлючевЫе слова: КОРОВЫ, КЕТОЗ, ГЛЮКОНЕОГЕНЕЗ, МЕТАБОЛИЗМ УГЛЕВОДОВ, АМИНОКИСЛОТЫ, ИНСУЛИН, КОРТИЗОЛ

Ketosis is a disease of ruminants characterized by profound metabolic disorders (mainly of carbohydrates, lipids and proteins) and accompanied by increased formation and a sharp increase in the content of ketone bodies in blood, urine and milk. There is a characteristic complex group of symptom in which ketonemia, ketonuria and ketonolactia are the main signs at the onset of the disease in cows [5]. The main etiological factor in the occurrence of ketosis is an energy deficit, foremost the lack of easily digested carbohydrates in the diet of cows with high milk yield [9]. To provide the organism with sufficient amount of energy during intensive lactation, cows need significantly more nutrients than they can eat with food. If the cow organism does not receive enough energy and nutrients with diet, internal reserves of the cow organism are used, which is accompanied by the strain in compensatory metabolic mechanisms.

An important role in the pathogenesis of ketosis belongs to amino acids, because they are involved in the synthesis of most endogenous biologically active compounds, structural proteins, enzymes, some hormones, nitrogenous bases, and neurotransmitters [3]. Metabolism of these compounds is controlled by various biochemical and physiological mechanisms that maintain the relatively constant concentration of amino acids in the blood and tissues.

The objective of the study was to investigate carbohydrate metabolism and plasma concentration of free amino acids in cows suffering from ketosis, which gives opportunity to obtain more profound insight into metabolic peculiarities occurring in this disease.

\section{Materials and methods}

The study was performed on cows of Holstein breed from second to fourth lactation with milk yield above $8000 \mathrm{~kg}$ per previous lactation. Animals were kept on farms in similar conditions and received the same diet. Cows were examined clinically, and the content of ketone bodies in urine was detected (express-test Ketophan, Pliva). 
Blood of animals was tested for the content of glucose, insulin, cortisol, amino acids, lactic and pyruvic acids. Animals with positive results for the presence of ketone bodies in urine were selected into a separate group. Blood samples were taken from jugular vein before morning feeding, into sterile tubes with heparin and immediately centrifuged at $3000 \mathrm{rpm}$. Obtained plasma was frozen at $-20{ }^{\circ} \mathrm{C}$ until analyses were done. The plasma levels of insulin and cortisol were measured using enzyme immunoassay analyzer and test-kits manufactured by "DRG". The plasma level of amino acids was determined using amino acid analyzer Biotronik LC 6001. And the level of glucose was measured within 1 hour from blood withdrawal by the glucose oxidase method. The whole blood was used for determination of pyruvic acid by the by the modified Umbright method, and of lactic acid using reaction with paraoxidiphenyl.

\section{Results and discussion}

During examination of ketotic cows it was revealed that some animals are lying up, they have quick lowering of live weight and yield, and look oppressed, some of them had muscular tremor. High level $(+++)$ of ketone bodies was detected in urine. Plasma level of glucose in sick animals was by $29.3 \%(\mathrm{P}<0.01)$ lower than in healthy animals (fig. 1).

Decreased glucose concentrations in the blood of sick cows should be construed as the result of inconsistency between the intake of energy with food and the consumption of glucose in metabolic processes and milk synthesis. The need for glucose in ruminants is by $90 \%$ or more provided by gluconeogenesis, which occurs predominantly in the liver $[5,8]$. In the period of intensive lactation mammary gland of cows needs a significant amount of glucose, which is mainly used for the lactose synthesis. Under conditions when requirement of glucose for lactose synthesis is high, and the supply of glucose precursors with diet is low, activation of gluconeogenesis is a vitally important compensatory mechanism [4]. These processes are regulated by endocrine system. In sick animals with low level of blood glucose, lowering of insulin concentration and increase of cortisol level was revealed. More specifically, in ketotic animals concentration of insulin was lower by $54.7 \%(\mathrm{P}<0.01)$ and level of cortisol was higher by $41 \%(\mathrm{P}<0.01)$ (fig. 1$)$ than in healthy animals; this should be considered as activation of compensatory mechanisms in organism of sick animals in conditions of metabolic energy deficit. Glucocorticoids, especially cortisol, induce key enzymes of gluconeogenesis, provide this process with starting compounds and reduce the requirement of tissues in glucose, and, accordingly, contribute to the growth of its blood concentration $[1,7]$. By stimulation of protein breakdown, cortisol promotes the release of amino acids, which are important elements of gluconeogenesis [6]. Some differences were established in the amino acid composition of blood plasma of healthy and sick cows. In the blood plasma of cows suffering from ketosis, the content of ketogenic amino acids is higher, and concentration of glycogenic amino acids is lower than in healthy animals. In particular, the content of phenylalanine, tyrosine and leucine in sick cows was by $22.2 \%(\mathrm{P}<0.05)$, $3.8 \%$ and $62.5 \%(\mathrm{P}<0.01)$ higher respectively in comparison with healthy animals (table). By contrast, the concentration of glycogenic amino acids such as alanine, arginine and asparagine in the blood plasma of cows suffering from ketosis was lower than in healthy animals by $19 \%, 32.8 \%$ and $30.2 \%$, respectively $(\mathrm{P}<0.05)$. Obviously, in order to compensate the energy deficiency, in organism of sick animals lipid oxidation processes are activated and ketogenic amino acids are used as energy sourse, which in its turn promotes the increase of ketone body content in blood.

Table

Plasma content of free amino acids in healthy and ketotic cows, $\mu \mathrm{mol} / \mathrm{L}(\mathrm{M} \pm \mathrm{m}, \mathrm{n}=25)$

\begin{tabular}{|l|c|c|c|}
\hline \multicolumn{1}{|c|}{ Amino acid } & Healthy & Ketotic & $\mathrm{P}<$ \\
\hline Phenylalanine & $24.3 \pm 0.53$ & $29.8 \pm 2.64$ & 0.05 \\
\hline Tyrosine & $27.6 \pm 2.05$ & $31.1 \pm 5.64$ & 0.5 \\
\hline Leucine & $48.6 \pm 2.30$ & $79.2 \pm 12.98$ & 0.01 \\
\hline Isoleucine & $70.5 \pm 6.22$ & $66.7 \pm 9.68$ & 0.1 \\
\hline Methionine & $16.8 \pm 1.48$ & $24.2 \pm 1.42$ & 0.01 \\
\hline Valine & $120.1 \pm 4.58$ & $10.5 \pm 5.42$ & 0.05 \\
\hline Alanine & $157.7 \pm 9.63$ & $118.4 \pm 4.93$ & 0.01 \\
\hline Arginine & $58.3 \pm 2.16$ & $46.6 \pm 2.58$ & 0.01 \\
\hline Asparagine & $25.2 \pm 1.93$ & $18.0 \pm 0.98$ & 0.05 \\
\hline Tryptophan & $38.6 \pm 2.95$ & $56.8 \pm 4.40$ & 0.01 \\
\hline
\end{tabular}



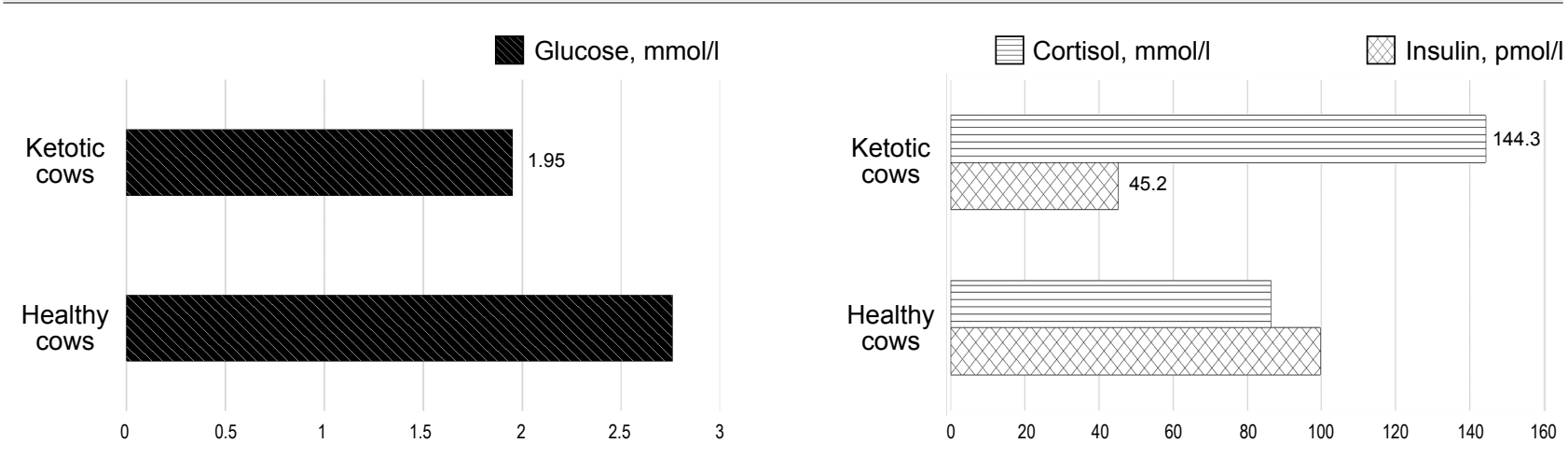

Fig. 1. Blood concentration of glucose, insulin and cortisol in healthy and ketotic cows $(\mathrm{n}=25)$

At the same time, such metabolic changes may be associated with the peculiarities of the breakdown of different groups of amino acids. In particular, aromatic and sulfur-containing amino acids, such as phenylalanine, tryptophan, tyrosine and methionine, are cleaved only in the liver. When liver is damaged due to ketosis, the activity of enzymes that disintegrate these amino acids is lowering, which obviously causes an increase of their blood levels [2]. At the same time it was found that in cows suffering from ketosis, the plasma content of methionine and tryptophan was higher by $30.6 \%$ and $32 \%(\mathrm{P}<0.01)$, respectively. By contrast, the concentration of branched chain amino acids such as valine and isoleucine was by $15.5 \%(\mathrm{P}<0.01)$ and $5.4 \%$ respectively lower than in healthy animals. It is known that valine and isoleucine are essential amino acids, which are metabolized mainly in muscle tissue and play significant role in energy metabolism, in particular in the formation and deposition of glycogen [3]. Thus, it can be argued that the imbalance of the amino acid composition of the blood in cows suffering from ketosis is an unfavorable factor for the course of the disease.
As a result of glucose and amino acids oxidation, pyruvic acid (pyruvate) is formed. Its degradation depends on the access of oxygen to the cells, i.e in anaerobic conditions, it is metabolized to lactic acid (lactate), and in aerobic condition pyruvate together with the ions of $\mathrm{H}^{+}$, penetrate into the mitochondria, where it is converted to acetic acid. It was established that in the blood of ketotic cows the content of pyruvate and lactate was higher by $43.2 \%$ and $69.4 \%(\mathrm{P}<0.01)$, respectively, in comparison with healthy cows (fig. 2).

The growth of these indicators in sick cows is obviously caused by disturbances in the hepatic function, because liver is an organ where the metabolism of these substances take place. Another reason for the increase in the content of lactate and pyruvate in the blood of ketotic cows is the activation of gluconeogenesis.

It should be noted that the increase in lactate-pyruvate ratio in sick animals (by $30.2 \%$, fig. 2), in comparison with healthy ones, indicates the predominance of anaerobic processes over aerobic ones in their organism.
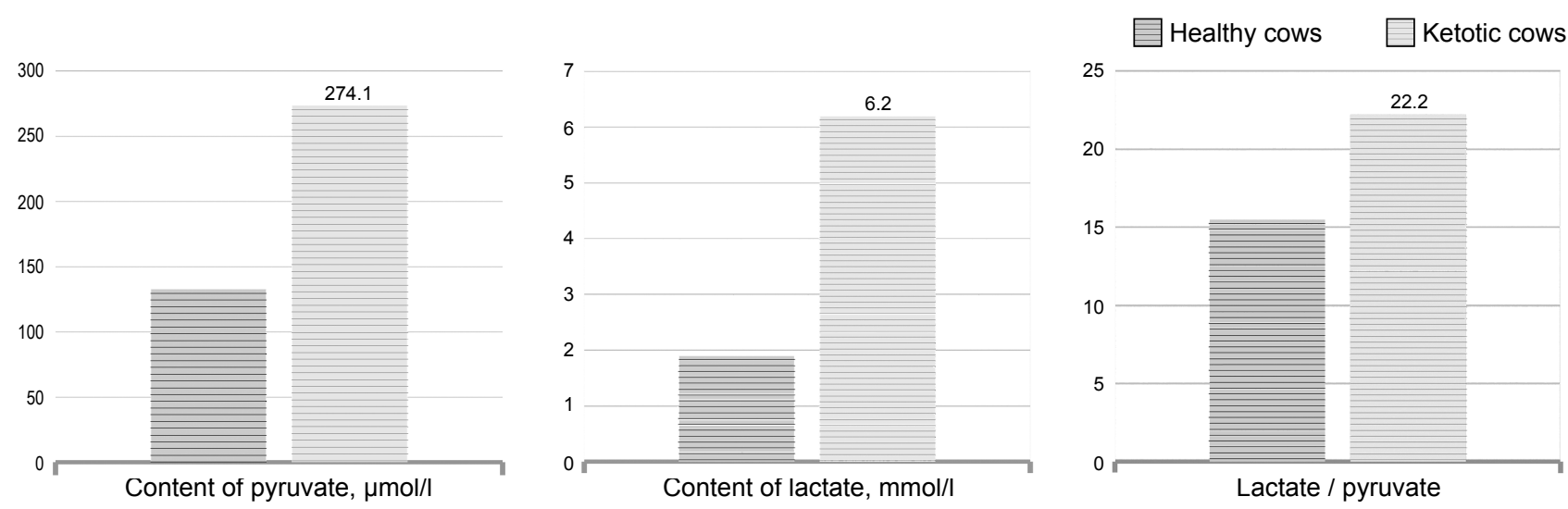

Fig. 2. Content of lactate, pyruvate and lactate/pyruvate ratio in healthy and ketotic cows $(n=25)$ 


\section{Conclusions}

1. Accumulation of ketone bodies in the blood of cows causes tension of compensatory mechanisms intended to compensate the energy deficit due to intensified gluconeogenesis.

2. A reliable decrease of the levels of glucose, insulin, glycogenic amino acids and increase of the concentration of cortisol, ketogenic amino acids, pyruvic acid and lactic acid is observed in blood of cows affected with ketosis in comparison with healthy animals.

3. Sick animals experience increase of lactate/pyruvate ratio by $30 \%$, which bears evidence of intensification of anaerobic processes in organism.

Perspectives of the future investigations. The prospect of further research is to develop effective measures aimed at intensification of the use of ketone bodies and correction of the energy deficit. The obtained data can serve as a theoretical basis for the development of informing diagnostic tests for ketosis of dairy cows.

1. Annison E. F., Bryden W. L. Perspectives on ruminant nutrition and metabolism Nutrition Research Reviews, 1999, vol. 12, issue 1, pp. 147-177. DOI: $10.1079 / 095442299108728866$.

2. D'Mello J. P. F. Amino Acids in Animal Nutrition. Edinburgh (UK), CABI Publishing, 2003, 526 p. DOI: $10.1079 / 9780851996547.0000$.
3. Lee H. H., Kida K., Miura R., Inokuma H., Miyamoto A., Kawashima C., Haneda S., Miyake Y.-I., Matsui M. Slow recovery of blood glucose in insulin tolerance test during the prepartum transition period negatively impacts the nutritional status and reproductive performance postpartum of dairy cows. Journal of Veterinary Medical Science, 2012, vol. 74, issue 4, pp. 457-464. DOI: $10.1292 /$ jvms.11-0302.

4. Levchenko V. I. (ed.), Vlizlo V. V., Kondrakhin I. P. Internal diseases of animals. Bila Tserkva, 2001, P. 2, $544 \mathrm{p}$.

5. Levchenko V. I. (ed.), Vlizlo V. V., Kondrakhin I. P. Internal diseases of animals. Bila Tserkva, 2015, P. 2, $610 \mathrm{p}$.

6. Petrukh I. M., Simonov M. R., Vlizlo V. V., Kaplinskyi V. V. Concentration of cortisol and ketogenic amino acids in cows blood for the treatment of ketosis. Scientific and technical bulletin of State Scientific Research Control Institute of Veterinary Medical Products and Fodder Additives and Institute of Animal Biology, 2017, vol. 18, issue 2, pp. 165-169.

7. Vlizlo V. Hormonal status in the affected cows with ketosis. Hungarian Veterinary J., 2015, vol. 137, issue 1, pp. 331-334.

8. Vlizlo V., Petruh I., Simonov M., Slivinska L. Hormonal regulation of energy metabolism in ketotic cows. XVIII Middle-European Buiatrics Congress, Eger (Hungary), 2018, pp. 294-298.

9. Vlizlo V. V., Simonov M. R., Hultiaieva O. V. Lipomobilization syndrome in dairy cows. Veterinary Medicine of Ukraine, 2014, vol. 11, pp. 23-26. 